TITLE:

\title{
Crt10 directs the cullin-E3 ligase Rtt101 to nonfunctional 25S rRNA decay.
}

AUTHOR(S):

Sakata, Tomoko; Fujii, Kotaro; Ohno, Mutsuhito; Kitabatake, Makoto

\section{CITATION:}

Sakata, Tomoko ...[et al]. Crt10 directs the cullin-E3 ligase Rtt101 to nonfunctional 25S rRNA decay.. Biochemical and biophysical research communications 2015, 457(1): 90-94

\section{ISSUE DATE: \\ 2015-01-30}

URL:

http://hdl.handle.net/2433/196087

\section{RIGHT:}

(c) 2014 Elsevier Inc. NOTICE: this is the author's version of a work that was accepted for publication in Biochemical and biophysical research communications. Changes resulting from the publishing process, such as peer review, editing, corrections, structural formatting, and other quality control mechanisms may not be reflected in this document. Changes may have been made to this work since it was submitted for publication. A definitive version was subsequently published in Biochemical and biophysical research communications, 457(1), 2015, doi:10.1016/j.bbrc.2014.12.072; This is not the published version. Please cite only the published version.; この論文は出版社版でありません。引用の際には 出版社版をご確認ご利用ください。 
Title:

"Crt10 directs the cullin-E3 ligase Rtt101 to nonfunctional 25S rRNA decay"

Authors:

Tomoko Sakata ${ }^{a}$, Kotaro Fujiia, Mutsuhito Ohno ${ }^{\text {**, Makoto Kitabatakea* }}$

Affiliation address:

a) Institute for Virus Research, Kyoto University, Shogoin-Kawaharacho 53, Sakyo-ku,

Kyoto 606-8507, Japan.

*) Corresponding authors:

Institute for Virus Research, Kyoto University, Shogoin-Kawaharacho 53, Sakyo-ku,

Kyoto 606-8507, Japan.

Tel: +81-75-751-3993; Fax: +81-75-751-3992

Email: hitoohno@virus.kyoto-u.ac.jp

Email:kmakoto@virus.kyoto-u.ac.jp

Abbreviations: 
NRD, nonfunctional rRNA decay; PTC, peptidyl-transferase center; CRL, cullin-RING

ubiquitin ligase complexes; Paf1C, Paf1 complex 


\section{$\underline{\text { ABSTRACT }}$}

Nonfunctional mutant ribosomal RNAs in $40 \mathrm{~S}$ or $60 \mathrm{~S}$ subunits are selectively degraded

in eukaryotic cells (nonfunctional rRNA decay, NRD). We previously reported that NRD of 25S rRNA required cullin-E3 ligase Rtt101 and its associating factor Mms1, both of which are involved in DNA repair. Although Mms22, an accessory component of the E3 complex, was suggested to direct the E3 complex to DNA repair, the factor that directs the complex to $25 \mathrm{~S}$ NRD currently remains unknown. We herein demonstrated that another accessory component, Crt10 was required for $25 \mathrm{~S} \mathrm{NRD,} \mathrm{but} \mathrm{not} \mathrm{for} \mathrm{DNA} \mathrm{repair,}$ suggesting that this accessory component specifies the function of the E3 complex differently. We also further divided Crt10-containing E3 complexes into sub-complexes, one of which contained the Paf1 complex, a Pol-II binding complex that modulates the transcription of stress-related genes. Our results showed the convergence of multiple pathways for stresses that harm nucleic acids and provided a molecular framework for the substrate diversity of the complex. (159 words)

Keywords: Ribosome, Quality Control, Ubiquitin E3 ligase 


\section{INTRODUCTION}

A number of quality control mechanisms have been identified in the production of ribosomal subunits [1]. Nonfunctional 18S rRNA with a deleterious mutation in its decoding center, and 25S rRNA with a peptidyl-transferase center (PTC) mutation, were both shown to be selectively eliminated from the cytoplasm of $S$. cerevisiae [2]. These quality control systems have been referred to as nonfunctional rRNA decay or NRD. In 2009, Cole et al demonstrated that Dom34 and Hbs1, previously reported factors in mRNA quality control, were involved in the decay of nonfunctional $18 \mathrm{~S}$ rRNA in $18 \mathrm{~S}$ NRD [3]. In the same year, our group reported that Mms1 and Rtt101 (also called as Cul8), previously identified as DNA repair factors [4,5], were required for 25S NRD [6]. Guided by the reported similarity in these two factors to the components of cullin-RING ubiquitin ligase (CRL) complexes, we found that they were essential for the selective ubiquitination of ribosomal particles containing nonfunctional $25 \mathrm{~S}$ rRNAs [6,7].

CRLs constitute a large family of E3 ubiquitin ligases [8], including the SCF (Skp1-cullin-F-box) complex. The SCF complex typically consists of Skp1, Cullin, Hrt1 (also called Rbx1 and Roc1), and one of the variable F-box-containing proteins. Cullin is 
a scaffold component of the complex that is connected by Skp1 to an F-box protein, a substrate recognition subunit of the ligase. One of the factors involved in $25 \mathrm{~S} \mathrm{NRD,}$ Rtt101, was shown to belong to the cullin family [9]. Interactions between Rtt101, Hrt1, and the E2 enzyme Cdc34 have already been reported [10,11]. On the other hand, Rtt101 lacks the Skp1-binding motif [10] and no F-box protein has been reported for Rtt101, which suggests that Mms1 may be a bridge protein that recruits substrate recognition subunits. One such candidate is $\mathrm{Mms22}$, which was previously shown to be indispensable for the function of Rtt101 and Mms1-containing E3 ligase in the DNA repair pathway [12]. However, since Mms22 is dispensable for NRD [6], the factor that directs the E3 ligase complex to the 25S NRD pathway has not yet been identified.

In the present study, we examined the binding partners of the E3 ligase complex and identified Crt10 as a factor that directed the ligase to the 25S NRD pathway. We showed that $25 \mathrm{~S}$ NRD was abolished in the crt10 strain while DNA repair activity was unaffected. We also revealed a stable interaction between the Crt10-containing complex and Paf1C, a complex associated with RNA polymerase II [13]. Since Paf1C was not required for 25S NRD, we concluded that the Crt10-containing E3 ligase complex could be further divided, indicating the functional complexity of this E3 ubiquitin ligase 
complex. 


\section{MATERIALS AND METHODS}

\section{Yeast strains and growth conditions}

The plasmids, strains, and primers used in this study are described in Supplemental table S1, S2, and S3. The Yeast knock-out strain collection and Tet-off Hughes collection (yTHC) were purchased from Open Biosystems. The Paf1 gene was manually disrupted with a kanamycin-resistant cassette from pFA6a-13Myc-kanMX6 [14].

To achieve expression from the Gal7 promoter, cells grown in SD medium containing $2 \%$ raffinose were diluted and grown in SD medium containing 2\% galactose, as described previously [6]. The Cdc34 tet-off strain of yTHC was grown in SD medium containing $2 \%$ galactose and $10 \mu \mathrm{g} / \mathrm{mL}$ Doxycycline (Dox, Sigma) for the Tet-off assay and was harvested 12 hours after the Dox treatment.

Serial dilutions of exponentially growing cultures of the indicated yeast strains were spotted onto YPD plates containing $20 \mu \mathrm{g} / \mathrm{ml}$ camptothecin (CPT, Wako Pure Chemical Industries), 0.01\% methyl methanesulfonate (MMS, Nacalai Tesque), or $250 \mu \mathrm{g} / \mathrm{ml}$ 
Congo Red (CR, Nacalai Tesque) for the sensitivity assay. Cells were grown for 2 days at $30^{\circ} \mathrm{C}$.

\section{RNA purification and qRT-PCR}

Total yeast RNA was purified by the MasterPure Yeast RNA Purification Kit (Epicentre Biotechnologies). A Northern analysis of tagged rRNAs was performed as previously described [6]. qRT-PCR was performed using the SuperScript III Platinum SYBR Green One-Step qRT-PCR Kit (Invitrogen) with the Applied Biosystems Step One Plus Real-time PCR System by the standard curve method. The primers MK251 and MK253 were used to quantify plasmid-derived tagged rRNA. To normalize tagged rRNA, the amount of non-tagged $25 \mathrm{~S}$ rRNA was measured by qRT-PCR with the primers Kota30 and Kota31 or the A260 Unit.

Immunoprecipitation and Western Blot

Immunoprecipitation by anti-Flag M2 agarose was performed as described previously [6]. Equal amounts of 3x Flag eluates were subjected to 5-20\% (Figure 2B) SDS-PAGE 
for immunoblotting. After transfer of the proteins to a nitrocellulose membrane (PROTRAN,

Whatman), the membrane was probed by an anti-Flag polyclonal antibody (1:1000, Sigma),

anti-Myc polyclonal antibody (1:2000, Sigma), or anti-HA monoclonal antibody (1:1000,

HA124, Nacalai Tesque). ECL (GE Healthcare) was used for visualization.

Purification of the Mms1-Crt10 complex

The wild type and Mms1-Flag/Crt10-HA strains expressing pA2451U were grown in $4 \mathrm{~L}$ of SD-galactose medium to the mid-log phase. The cell pellet was frozen and ground in liquid nitrogen using a mortar and pestle. The resulting cell powder was then resuspended on ice in IP buffer (50 mM HEPES-KOH (pH7.5), $150 \mathrm{mM} \mathrm{NaCl}, 2.5 \mathrm{mM}$ MgCl2, 0.1\% NP-40, 0.1M PMSF) supplemented with a protease inhibitor cocktail. Extracts were clarified by centrifugation at $4^{\circ} \mathrm{C}$ for $5 \mathrm{~min}$ at $5,000 \times \mathrm{g}$ and for $20 \mathrm{~min}$ at $18,000 \times g$. The lysate was then mixed with anti-Flag M2 agarose beads and rotated at $4^{\circ} \mathrm{C}$ overnight. The resin was washed with IP buffer and then incubated with IP buffer containing $0.1 \mathrm{mg} / \mathrm{mL} 3 \mathrm{x}$ Flag peptides. 3x Flag eluates were filtered and rotated with anti-HA monoclonal antibody magnet beads (MBL) at $4^{\circ} \mathrm{C}$ overnight for the second immunoprecipitation. The beads were washed with IP buffer and boiled with SDS 
sample buffer (62.5 mM Tris- $\mathrm{HCl}$ (pH6.8), 2\% SDS, 10\% glycerol, 5\% 2-mercaptoethanol, and $0.02 \%$ Bromophenol blue) for elution. The eluates were subjected to 5 -20\% gradient SDS-PAGE, and the proteins were visualized by silver staining and excised separately from the gel. 


\section{RESULTS AND DISCUSSION}

\section{Crt10 was required for $25 \mathrm{~S}$ NRD}

The aim of this study was to identify the factors that physically linked the

Mms1-containing E3 ligase complex and nonfunctional ribosomes. To analyze the involvement of known Mms1-binding proteins in 25S NRD, we selected 6 nonessential genes and 1 essential gene for our initial analysis $[10,15,16,17]$.

We used the 25S NRD reporter plasmid developed previously [6] (Figure 1A). With this plasmid, nonfunctional mutant $25 \mathrm{~S}$ rRNA with an 18-nt tag sequence in its nonessential loop was transcribed from the RNA Pol II promoter, the Gal7 promoter. The tag sequence was used to quantify the $25 \mathrm{~S}$ NRD substrate by Northern blotting or qRT-PCR. We introduced point mutations into the PTC to make the rRNA nonfunctional.

When Cdc34, an E2 enzyme, was depleted by the Tet-off system, all of the nonfunctional 25S rRNA mutants tested accumulated in the cells (Figure 1B), confirming that the 
Mms1 complex functioned in 25S NRD by associating with Cdc34. Most of the nonessential genes analyzed in Supplementary Figure 1 were not involved in degrading the 25S NRD substrate, A2451U, which was consistent with CRLs using multiple accessory components in distinct pathways. In contrast, the $25 \mathrm{~S}$ NRD substrate accumulated in the crt10 strain.

In order to determine whether the crt104 strain also accumulated in other nonfunctional 25S rRNA mutants, two mutant 25S rRNAs, C2452G and U2585A, were expressed in the crt10 4 strain and the relative amount of tagged $25 \mathrm{~S}$ rRNAs was measured by the qRT-PCR assay. As shown in Figure 1C, all of the tested mutant 25S rRNAs accumulated in the crt10 strain. The increase observed in nonfunctional $25 \mathrm{~S}$ rRNAs disappeared when functional Crt10 was provided by the expression plasmid. These results clearly indicated that Crt10 was involved in the cellular level of nonfunctional 25S rRNAs.

The accumulation of nonfunctional $25 \mathrm{~S}$ rRNAs in the crt10 strain was attributed to a reduction in their degradation by $25 \mathrm{~S}$ NRD. To clarify this issue, we investigated the stability of nonfunctional mutant $25 \mathrm{~S}$ rRNAs in this strain. 
The transcription of a mutant rRNA could be shut off in our reporter system (Figure 1A) by replacing the growth media from galactose-containing media to glucose-containing media. After the transcriptional shut-off, cells were harvested at several time points and the stability of nonfunctional mutant $25 \mathrm{~S}$ rRNAs was examined by Northern blotting using a probe designed for the tag sequence (Figure 1D).

In the wild type strain, all three nonfunctional mutant $25 \mathrm{~S}$ rRNAs were degraded during the assay and showed a wide range of half-lives (Figure 1D). In contrast, all of these RNAs were mostly stabilized in the crt10 strain. We concluded that Crt10 was required for the degradation step of nonfunctional rRNAs in $25 \mathrm{~S} \mathrm{NRD}$, as was previously reported for both Mms1 and Rtt101 [6].

\section{Crt10 was required for ubiquitination of nonfunctional ribosomes}

When the sucrose density sedimentation assay was performed with the crt104 strain, we noted that the distribution pattern of nonfunctional mutant rRNAs was similar to that in the mms14 strain. The signals in the $80 \mathrm{~S}$ as well as $60 \mathrm{~S}$ fractions were more 
intensified in the crt104 strain (Supplementary Figure 2, crt104) than in the wild type strain (Supplementary Figure 2, wild type).

Since the $\operatorname{crt10\Delta }$ strain has a similar phenotype to the $m m s 1 \Delta$ strain in the above assay, and because a physical interaction has been reported previously between Mms1 and Crt10 [10], we assumed that these two factors were involved in the same step of $25 \mathrm{~S}$ NRD as a complex. We performed a genetic epistasis analysis for these two factors to provide additional evidence to support this interpretation. The double mutant strain mms $1 \Delta \operatorname{crt} 10 \Delta$ was created for this purpose.

As is clearly indicated in Figure 2A, the stabilization of each nonfunctional 25S rRNA was partial in both the mms $1 \Delta$ strain and $\operatorname{crt10\Delta }$ strain. The accumulation patterns of different nonfunctional rRNAs in these two single mutant strains were similar. When the mms14crt10 double mutant strain was examined, we observed the partial stabilization pattern of mutant $25 \mathrm{~S}$ rRNAs, which were indistinguishable from those in each single mutant strain (Figure 2A). These results support a model in which Mms1 and Crt10 function in the same process of $25 \mathrm{~S} \mathrm{NRD,} \mathrm{ribosomal} \mathrm{ubiquitination.} \mathrm{To}$ 
confirm this model, we expressed A2451U nonfunctional $25 \mathrm{~S}$ rRNA in the crt10 4 strain and examined ubiquitination of the ribosomal fraction of this strain (Figure 2B).

As we previously reported [6], the overexpression of A2451U in the wild type strain enhanced the ubiquitination of ribosomal particles (Figure 2B, compare lanes 3 and 4). These ubiquitin signals were dependent on Mms1 (Figure 2B, lanes 5 and 6). As we predicted, the same phenotype was confirmed for the crt104 strain; the ubiquitinated proteins at 40,50 , and $60-\mathrm{kDa}$, characteristic of $\mathrm{A} 2451 \mathrm{U}$ expression, were hardly observed in this strain (Figure 2B, lanes 7 and 8 compared to lanes 3 and 4 ). These results clearly demonstrated that Crt10 was required for the ubiquitination of nonfunctional ribosomes.

A simple interpretation for the aforementioned results was that Crt10 was required for the activity of the E3 ligase complex. On the other hand, Crt10 may also have contributed to the stability of Mms1 or Rtt101. If the latter is the case, the depression of 25S NRD in the crt104 strain can be attributed solely to the decrease in Mms1 or Rtt101, and not to the functional modulation of the E3 ligase. To exclude the latter possibility, we measured the amount of Mms1 and Rtt101 in the wild type and crt104 
strain. As shown in Supplementary Figure 3, the deletion of Crt10 did not reduce Mms1 or Rtt101. We concluded that Crt10 was required for the function of the E3 complex.

3. Paf1C physically associated with Crt10 and Mms1, but not was involved in 25S NRD

To obtain a deeper insight into the function of Crt10, a pull-down experiment was performed to identify the factors associating with the Crt10-Mms1 complex. We created a strain that expressed Mms1-Flag and Crt10-HA from their native promoters to purify the E3 ligase complex by sequential immunoprecipitation (Figure 3A, 3B and Supplementary Figure 4). We found that the major binding partner of the Crt10-Mms1 complex was the Paf1 complex (Paf1lC), an RNA polymerase II-binding complex that regulates the transcription levels of stress-related genes [13]. This result prompted us to examine the involvement of Paf1C in 25S NRD. However, as shown in Figure 3C and $3 \mathrm{D}$, we did not detect any defect in $25 \mathrm{~S} \mathrm{NRD}$ in the paf14 strain, suggesting that the function of the Crt10-containing E3 complex can be further divided.

We reasoned that Paf1C could be a substrate of this E3 complex. We next determined whether the expression level of Paf1C was up-regulated in the absence of this complex 
(Supplementary Figure 5). The flag-tagged Paf1C components, Paf1p, Cdc73p, and Leo1p, were expressed and detected by Western Blot (compare lanes 2, 6, and 10 to lane 1 for the wild type strain). The signals of the Paf1C components were increased in the crt104 strain (compare lanes 4, 8, and 12 with lanes 2, 6, and 10, respectively). Similar increases were observed in the mms $1 \Delta$ strain (compare lanes 3, 7, and 11 with lanes 2, 6, and 10, respectively), as expected. A previous study reported that each component of Paf1C was unstable in the deletion strain of Ctr9, one of the components of Paf1C [18]. This effect was also confirmed in our strains (lanes 5, 9, and 13), indicating that the measurement of these tagged proteins was quantitative. These results led us to conclude that Crt10 partly affected the abundance of Paf1C in vivo.

The increase in Paf1C components described above was modest. One explanation for this is that only a limited population of Paf1C constituted the targets of the E3 ligase. Consistent with this model, when we examined the effects of the Crt10 deletion on the function of Paf1C by the qRT-PCR assay, we could not see any change in the mRNA expression levels of Paf1C-controlled genes (Supplementary Figure 6). 
We also investigated the effects of the Crt10 deletion on the function of Paf1C in a phenotypic assay. A previous study reported that the paf14 stain was susceptible to Congo Red (CR) for defects in cell wall assembly [19]. This phenotype was reproduced (Figure 4A). However, we found that the crt104 strain was not sensitive to CR, suggesting that Crt10 was not required for the function of Paf1C in this system. We also demonstrated that Mms1 and Rtt101 were not fully required for CR resistance, although partial growth retardation was observed for both deletion strains.

Although the effects of the Crt10 deletion on the function of Paf1C were not observed in the drug-resistance assay, we noted an interesting feature during the experiment. As Mms1 and Rtt101 are involved in DNA repair, the mms1A strain and $r t t 101 \Delta$ strain are hypersensitive to DNA-damaging drugs such as MMS and CPT (Figure 4A, compare the mms14 or rtt1014 strain with the wild type strain). In the case of Mms22, another binding partner of Mms1 and Rtt101, the $m_{m} 224$ stain was also sensitive to these drugs (Figure 4A, mms224). However, the crt104 strain was resistant to both of these conditions (Figure 4A, crt104). These results clearly indicated that the 25S NRD pathway was genetically segregated from the DNA repair pathway. 
5. Crt10 defined substrate recognition of the Mms1-Rtt101-containing E3 ligase $\underline{\text { complex }}$

Binding of the Mms1-Rtt101 complex with Crt10 or Mms22 was previously shown to be mutually exclusive. In this study, we showed that Crt10 was required for $25 \mathrm{~S}$ NRD, but not for DNA repair, and vice versa for Mms22. These results clearly indicated that these accessory factors modulated the function of the E3 ligase complex differently and independently. We also further divided Crt10-containing E3 complexes into sub-complexes, one of which contained Paf1C.

Although the significance of Crt10 binding to Paf1C currently remains unclear, these results broaden our understanding of the function of this E3 ligase complex in various pathways. It is of particular interest to note that the factors associating with the Mms1-Rtt101 complex, Crt10, Paf1C, and Mms22, were all related to stress response pathways $[10,20]$. We presumed that a series of distinct, but related pathways were coordinated by this E3 complex to reserve prompt responses to various defects against various DNA/RNA-damaging stresses. Further analyses of this E3 complex will assist 
in elucidating this intricate system. 


\section{ACKNOWLEDGMENTS}

We thank Drs. Philippe Pasero and Jérôme Poli for sharing unpublished results. We thank Drs. Ichiro Taniguchi, Kodai Sano, and Tokie Sakai for their technical advice and discussions, and Drs. Kaori Shinmyozu and Akira Nakamura for mass spectrometry analyses. The yeast strain (BY20693) was provided by the National Bio-Resource Project (NBRP) of the MEXT, Japan. T.S. and K.F. are JSPS (Japan Society for the Promotion of Science) Research Fellows. This work was supported by Ministry of Education, Culture, Sports, Science and Technology of Japan (MEXT), [26440004 to M.K., 26113004 to M.O.] and Takeda Science Foundation to M.K.

\section{Appendix A. Supplementary data}

Supplementary data associated with this article can be found in the online version at http://XXXXXXXX.

\section{REFERENCES}

[1] D.L.J. Lafontaine, A 'garbage can' for ribosomes: how eukaryotes degrade their ribosomes, Trends in Biochemical Sciences 35 (2010) 267-277. 
[2] F.J. LaRiviere, S.E. Cole, D.J. Ferullo, M.J. Moore, A late-acting quality control process for mature eukaryotic rRNAs, Molecular Cell 24 (2006) 619-626.

[3] S.E. Cole, F.J. LaRiviere, C.N. Merrikh, M.J. Moore, A Convergence of rRNA and mRNA Quality Control Pathways Revealed by Mechanistic Analysis of Nonfunctional rRNA Decay, Molecular Cell 34 (2009) 440-450.

[4] L. Prakash, S. Prakash, ISOLATION AND CHARACTERIZATION OF MMS-SENSITIVE MUTANTS OF SACCHAROMYCES-CEREVISIAE, Genetics 86 (1977) 33-55.

[5] D.T. Scholes, M. Banerjee, B. Bowen, M.J. Curcio, Multiple regulators of Tyl transposition in Saccharomyces cerevisiae have conserved roles in genome maintenance, Genetics 159 (2001) 1449-1465.

[6] K. Fujii, M. Kitabatake, T. Sakata, A. Miyata, M. Ohno, A role for ubiquitin in the clearance of nonfunctional rRNAs, Genes \& Development 23 (2009) 963-974.

[7] K. Fujii, M. Kitabatake, T. Sakata, M. Ohno, 40S subunit dissociation and proteasome-dependent RNA degradation in nonfunctional 25S rRNA decay, Embo Journal 31 (2012) 2579-2589.

[8] E.S. Zimmerman, B.A. Schulman, N. Zheng, Structural assembly of cullin-RING ubiquitin ligase complexes, Current Opinion in Structural Biology 20 (2010) 
714-721.

[9] J.J. Michel, J.F. McCarville, Y. Xiong, A role for Saccharomyces cerevisiae Cul8 ubiquitin ligase in proper anaphase progression, Journal of Biological Chemistry 278 (2003) 22828-22837.

[10] I.W. Zaidi, G. Rabut, A. Poveda, H. Scheel, J. Malmstroem, H. Ulrich, K. Hofmann, P. Pasero, M. Peter, B. Luke, Rtt101 and Mms1 in budding yeast form a CUL4(DDB1)-like ubiquitin ligase that promotes replication through damaged DNA, Embo Reports 9 (2008) 1034-1040.

[11] E. Duro, J.A. Vaisica, G.W. Brown, J. Rouse, Budding yeast Mms22 and Mms1 regulate homologous recombination induced by replisome blockage, DNA Repair 7 (2008) 811-818.

[12] J.A. Vaisica, A. Baryshnikova, M. Costanzo, C. Boone, G.W. Brown, Mms1 and Mms22 stabilize the replisome during replication stress, Molecular Biology of the Cell 22 (2011) 2396-2408.

[13] B.N. Tomson, K.M. Arndt, The many roles of the conserved eukaryotic Paf1 complex in regulating transcription, histone modifications, and disease states, Biochimica Et Biophysica Acta-Gene Regulatory Mechanisms 1829 (2013) 116-126.

[14] J. Bahler, J.Q. Wu, M.S. Longtine, N.G. Shah, A. McKenzie, A.B. Steever, A. Wach, P. 
Philippsen, J.R. Pringle, Heterologous modules for efficient and versatile PCR-based gene targeting in Schizosaccharomyces pombe, Yeast 14 (1998) 943-951.

[15] S. Mimura, T. Yamaguchi, S. Ishii, E. Noro, T. Katsura, C. Obuse, T. Kamura, Cul8/Rtt101 Forms a Variety of Protein Complexes That Regulate DNA Damage Response and Transcriptional Silencing, Journal of Biological Chemistry 285 (2010) 9858-9867.

[16] N.J. Krogan, G. Cagney, H.Y. Yu, G.Q. Zhong, X.H. Guo, A. Ignatchenko, J. Li, S.Y. Pu, N. Datta, A.P. Tikuisis, T. Punna, J.M. Peregrin-Alvarez, M. Shales, X. Zhang, M. Davey, M.D. Robinson, A. Paccanaro, J.E. Bray, A. Sheung, B. Beattie, D.P. Richards, V. Canadien, A. Lalev, F. Mena, P. Wong, A. Starostine, M.M. Canete, J. Vlasblom, S. Wu, C. Orsi, S.R. Collins, S. Chandran, R. Haw, J.J. Rilstone, K. Gandi, N.J. Thompson, G. Musso, P. St Onge, S. Ghanny, M.H.Y. Lam, G. Butland, A.M. Altaf-Ui, S. Kanaya, A. Shilatifard, E. O'Shea, J.S. Weissman, C.J. Ingles, T.R. Hughes, J. Parkinson, M. Gerstein, S.J. Wodak, A. Emili, J.F. Greenblatt, Global landscape of protein complexes in the yeast Saccharomyces cerevisiae, Nature 440 (2006) 637-643.

[17] Y. Fu, W. Xiao, Identification and characterization of CRT10 as a novel regulator of Saccharomyces cerevisiae ribonucleotide reductase genes, Nucleic Acids Research 34 
(2006) 1876-1883.

[18] C.L. Mueller, S.E. Porter, M.G. Hoffman, J.A. Jaehning, The Paf1 complex has functions independent of actively transcribing RNA polymerase II, Molecular Cell 14 (2004) 447-456.

[19] K.-Y. Kim, D.E. Levin, Mpk1 MAPK Association with the Paf1 Complex Blocks Sen1-Mediated Premature Transcription Termination, Cell 144 (2011) 745-756.

[20] J.L. Betz, M. Chang, T.M. Washburn, S.E. Porter, C.L. Mueller, J.A. Jaehning, Phenotypic analysis of Paf1/RNA polymerase II complex mutations reveals connections to cell cycle regulation, protein synthesis, and lipid and nucleic acid metabolism, Molecular Genetics and Genomics 268 (2002) 272-285. 


\section{FIGURE LEGENDS}

Figure 1 Crt10 was required for the degradation of mutant $25 \mathrm{~S}$ rRNAs.

(A) The transcription unit of the 25S NRD reporter plasmid used in this study. Full length 35S rRNA was transcribed from the Pol-II promoter, the GAL7 promoter. The 18-nt short tag sequence was inserted into the nonessential loop near the 5 ' end of $25 \mathrm{~S}$ rRNA to detect plasmid-transcribed 25S rRNA. Two primers, MK251 and 253, were designed at the indicated locations to quantify tagged $25 \mathrm{~S}$ rRNAs by qRT-PCR. When indicated, the point mutation A2451U (E.coli numbering) was introduced into PTC.

(B) qRT-PCR quantification of 18-nt tagged wild type (WT) or mutant (A2451U, C2452G, and U2585A) rRNAs in a Cdc34 tet-off strain in the presence (Dox+) and absence (Dox-) of doxycycline (Dox). Strains expressing tagged rRNAs were grown in SD-galactose medium to the mid-log phase and harvested 12 hours after the administration of Dox. The tagged rRNAs were quantified by qRT-PCR. The amount of tagged rRNA was normalized using non-tagged 25S RNA quantified by another set of primers.

(C) Quantification of wild type and nonfunctional mutant 25S rRNAs (A2451U, C2452G, and U2585A) in the crt104 strain by the qRT-PCR assay. Tagged rRNAs were normalized as in (A). +pCrt10-HA; A plasmid producing Crt10-HA was introduced into 
the $\operatorname{crt} 10 \Delta$ strain for the expression of tagged $25 \mathrm{~S}$ rRNAs.

(D) Time-course experiments with tagged rRNA mutants. At time 0 , the medium was replaced by SD-glucose to shut-off transcription of the tagged rRNAs from the GAL7 promoter. Cells were harvested at the indicated time points and RNA was separated by $1 \%$ agarose and analyzed by Northern blotting for the tag sequence. Images from the longer exposure film are shown for panels with faint signals.

Figure 2 Crt10 functioned in the Mms1 pathway of 25S NRD.

(A) The accumulation level of mutant rRNAs in an mms14crt10 double mutant and related single mutant strains measured by the qRT-PCR assay. The amount of tagged rRNA was normalized by qRT-PCR of endogenous rRNA.

(B) Effects of A2451U overexpression on the ubiquitination pattern of ribosomal fractions of the crt10 strain. Tagged wild type (WT1) or nonfunctional mutant (A2451U) 25S rRNAs were overexpressed, together with Myc-tagged ubiquitin expression. Ribosomal fractions were obtained from lysates using the immunoprecipitation of Rpl11a-Flag and resolved in 5-20\% SDS-PAGE. The ubiquitination of proteins was visualized by an anti-Myc polyclonal antibody. The 
bottom panel shows an immunoblot of the same membrane with the anti-Flag antibody.

The intensified bands caused by nonfunctional rRNAs are indicated by arrowheads.

Figure 3 Paf1C physically associated with Crt10 and Mms1, but not was involved in 25S

$\underline{\text { NRD. }}$

(A) The silver staining pattern of the complex containing Crt10 and Mms1. The Mms1/Crt10 complex was purified by two-step immunopurification. A wild type strain with no tagged gene was used as a negative control (lane 1) for the same set of sample preparation procedures and analyses. Protein bands enriched in the Mms1-Flag/Crt10-HA fraction (lane 2) were analyzed by mass spectrometry. The identities of the protein bands are indicated on the right side of the figure.

(B) Co-immunoprecipitation of Crt10 with the Paf1C components, Paf1 and Leo1.

Paf1-Flag and Leo1-Flag were expressed and immunoprecipitated by an anti-Flag antibody from yeast extracts expressing Crt10-HA. The co-immunoprecipitation of Crt10-HA by Paf1C components was examined by immunoblotting for the anti-HA antibody. The bottom panels show the efficiency of the precipitation of Flag-tagged proteins in these experiments. 
(C) qRT-PCR quantification of wild type (WT) and mutant rRNA (A2451U) in the wild type and paf14 strains. The amount of tagged rRNA was normalized by qRT-PCR of endogenous rRNA.

(D) Time-course experiments with tagged mutant (A2451U) rRNA in the wild type and paf1A strains. Cells were grown in SD-Galactose and the media was replaced by SD-Glucose to stop transcription from the GAL7 promoter. RNAs were prepared at the indicated time points after the transcriptional shut-off of the tagged rRNAs and analyzed by Northern blotting for the tag sequence. An image of the same membrane with longer exposure is shown for the panel with weak signals.

Figure 4 Disruption of Crt10 genetically segregated 25S NRD from the DNA repair pathway.

(A) The 25S NRD and DNA repair pathways were genetically segregated by the crt10 strain. Mutant strains were grown in YPD overnight at $30^{\circ} \mathrm{C}$ and were serially diluted in 10 -fold increments. Five microliters of each of the serial dilutions was spotted onto YPD plates containing $20 \mathrm{\mu g} / \mathrm{mL}$ of camptothecin (CPT), $0.01 \%$ methyl methanesulfonate (MMS), or $250 \mu \mathrm{g} / \mathrm{mL}$ Congo Red (CR). These plates were incubated at $30^{\circ} \mathrm{C}$ for 2 days and photographed. 
(B) Model for the proposed role of Crt10. 
A

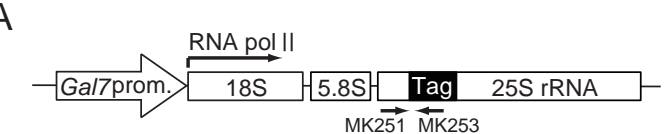

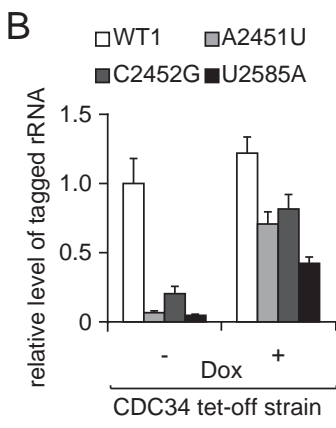

C aWT1 पA2451U
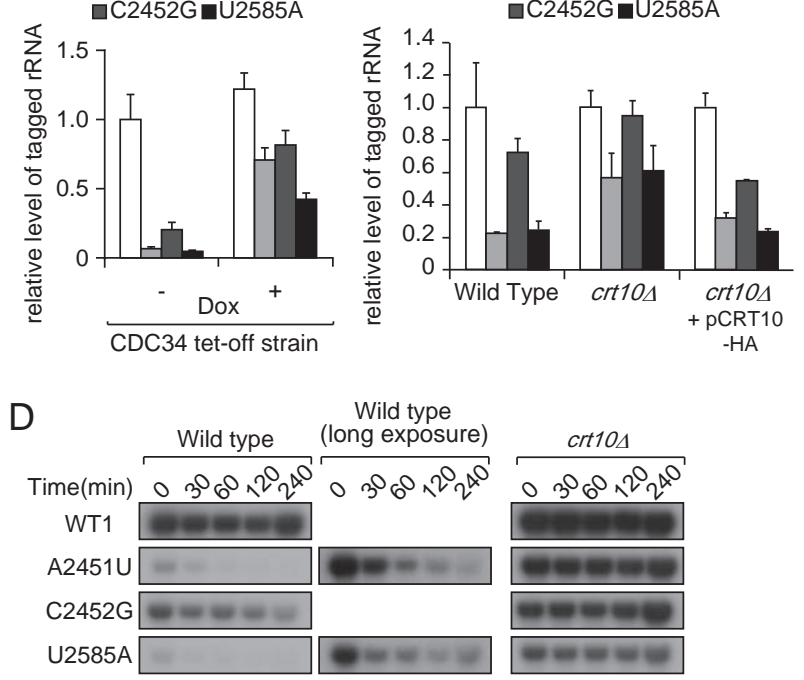

Fig.1 SAKATA et al.

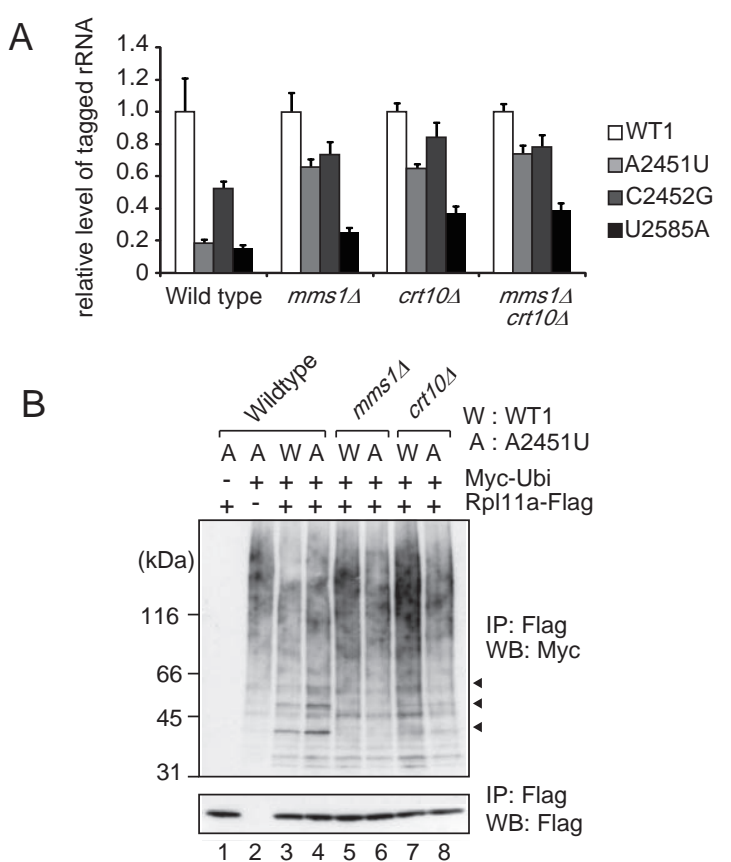

Fig.2 SAKATA et al. 
A

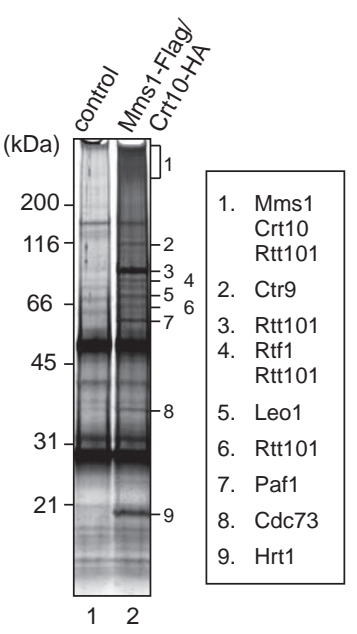

B

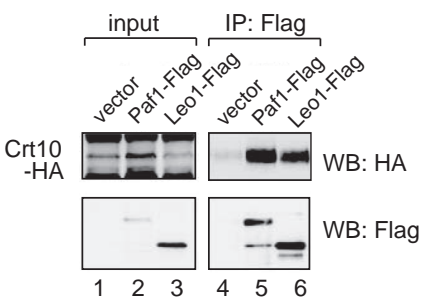

C

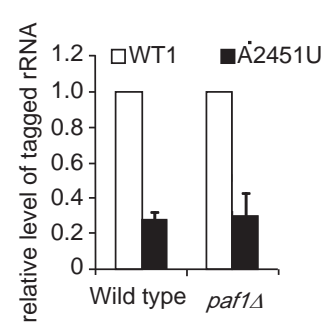

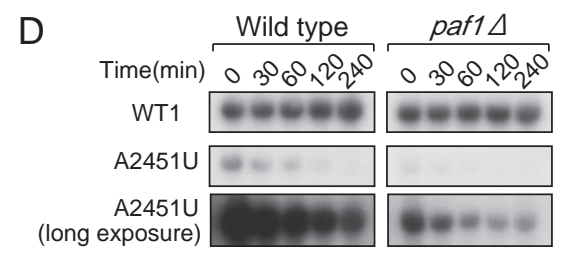

Fig.3 SAKATA et al.

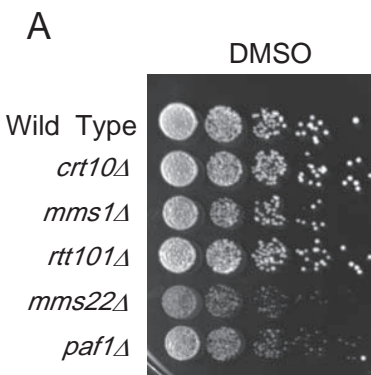

$20 \mu \mathrm{g} / \mathrm{ml} \mathrm{CPT}$

$0.01 \% \mathrm{MMS}$
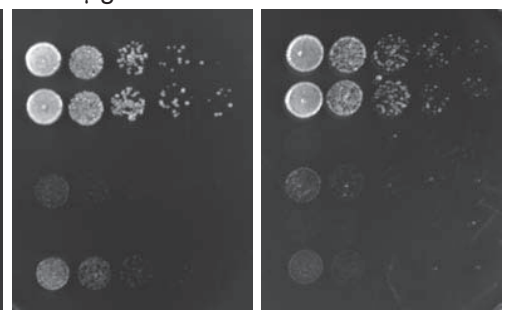

$250 \mu \mathrm{g} / \mathrm{ml} \mathrm{CR}$

B
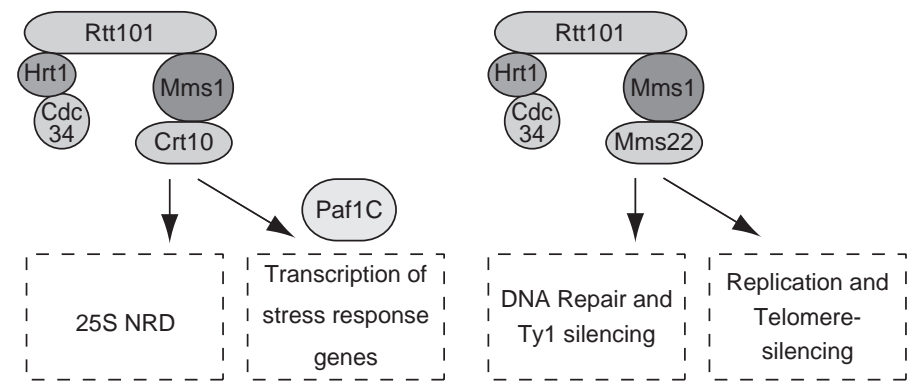

Fig.4 SAKATA et al. 


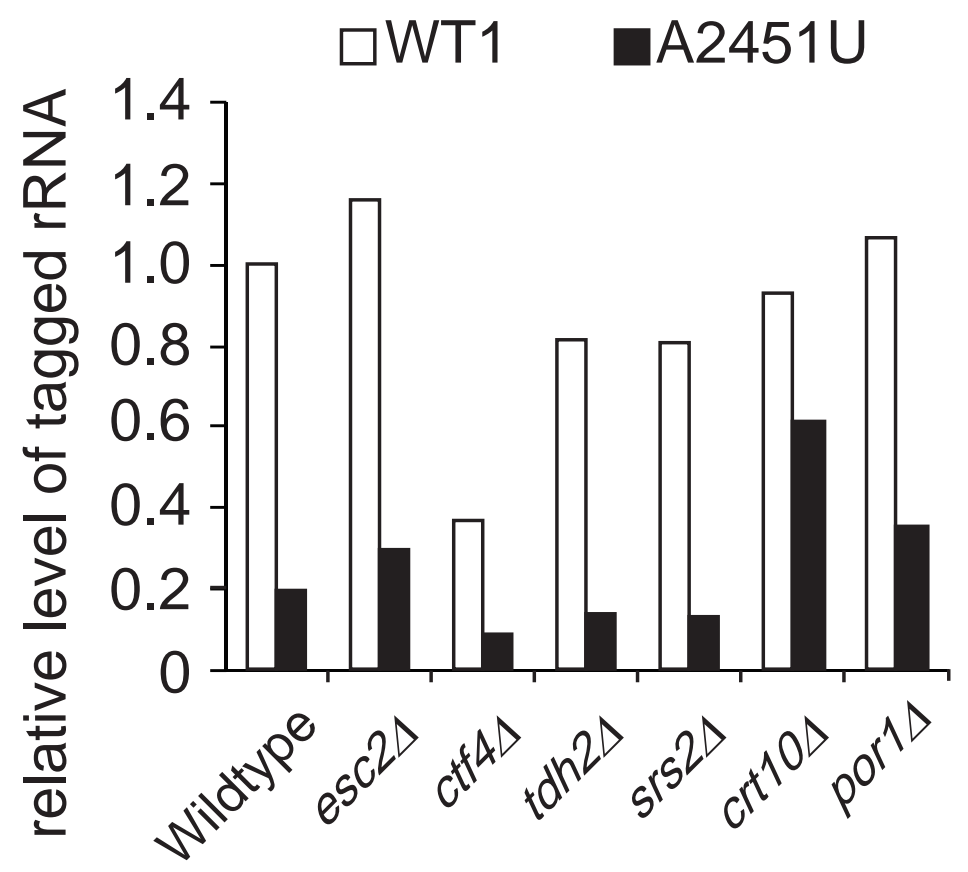

Figure S1. qRT-PCR quantification of tagged wild type (WT) and mutant (A2451U) rRNA in deletion mutants of Mms1-interacting proteins.

Tagged rRNAs were quantified by qRT-PCR. The amount of tagged rRNAs was normalized by the A260 unit of the input solution of RNA. 


\section{Supplementary Figure S2}
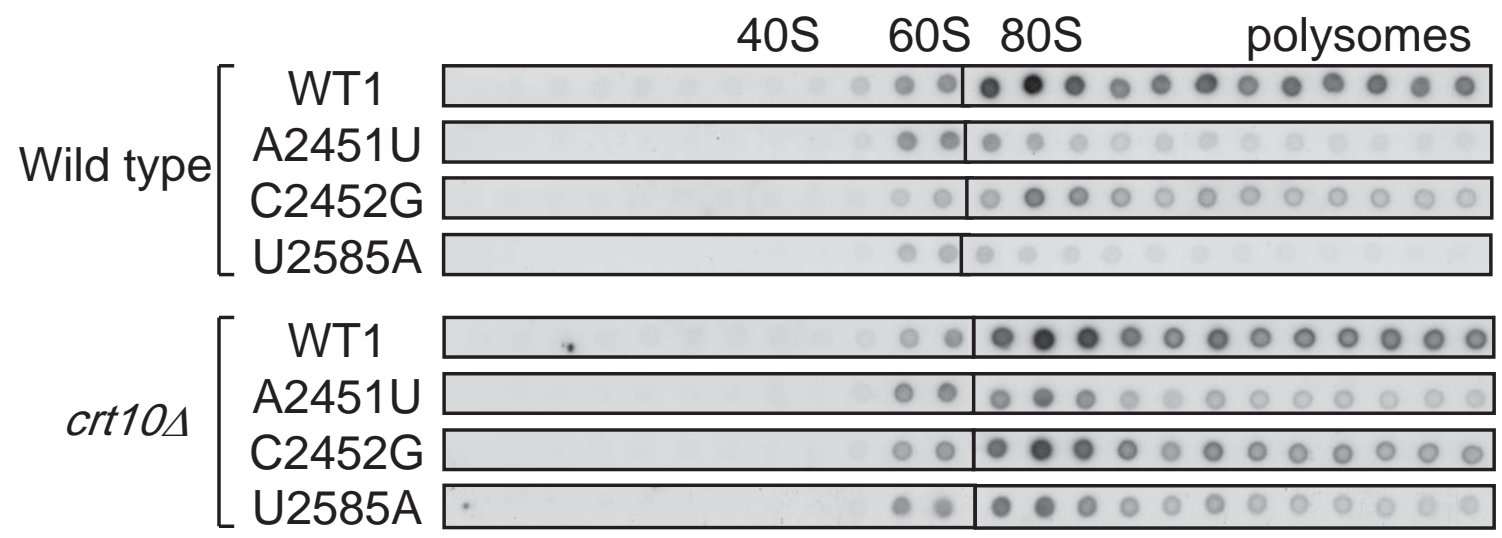

Figure S2. Sucrose density gradient sedimentation of mutant $25 S$ rRNAS in the wild type or crt10 $\triangle$ strain.

Cell lysates were resolved on a $10-40 \%$ sucrose gradient and tagged rRNAs were visualized by Northern blotting. Signals in the same panel came from the same membrane. 


\section{Supplementary Figure S3}

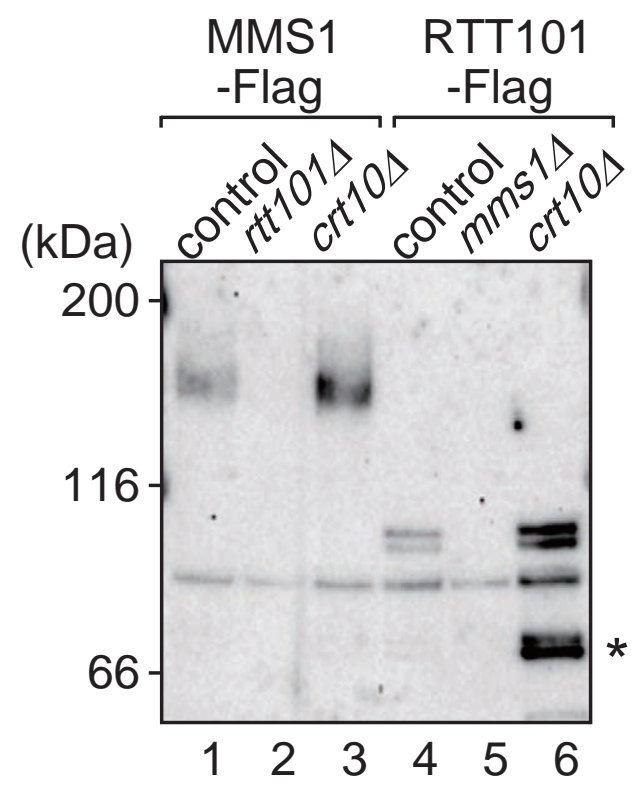

Figure S3. Expression levels of Mms1 and Rtt101 in strains with different backgrounds.

Genomically tagged Mms1-Flag, Rtt101-Flag, or Crt10-Flag expressed in the indicated deletion strains were concentrated by immunoprecipitation with an anti-Flag antibody. The precipitates were analyzed by immunoblotting with the anti-Flag antibody. Proteolytic fragments of Rtt101-Flag are indicated with an asterisk. 


\section{Supplementary Figure S4}

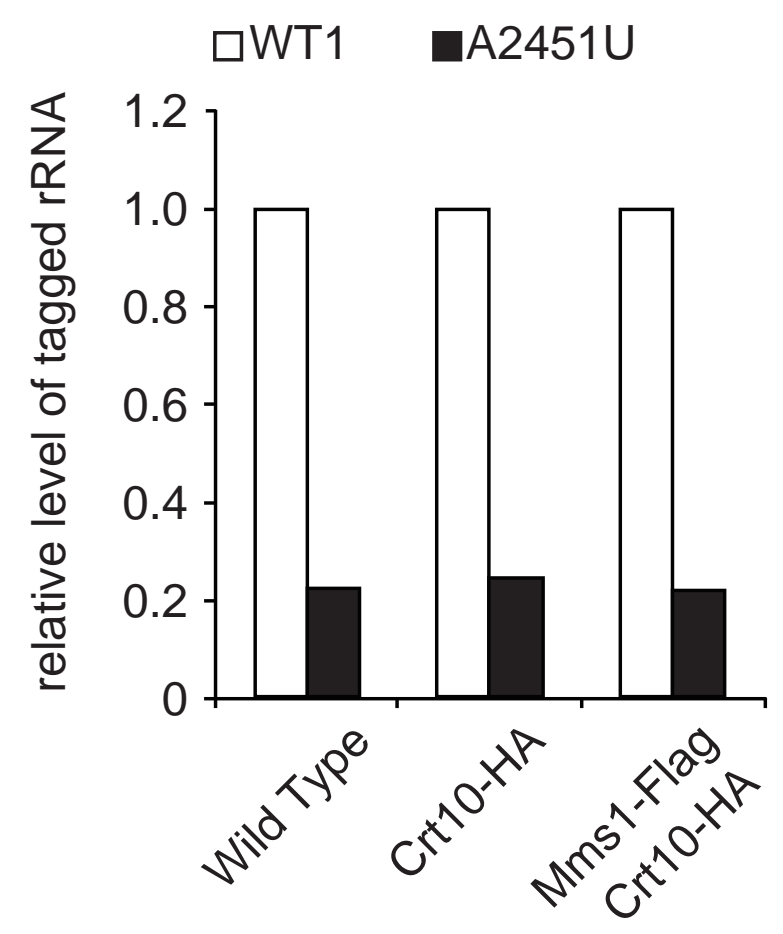

Figure S4. The efficiency of 25S NRD. Wild type, a strain with genomically tagged Crt10-HA, and Crt10-HA Mms1-Flag double tagged strains were used for expression of the 25S NRD substrate with or without the A2451U mutation. The amount of 18-nt tagged 25S rRNAs was quantified by qRT-PCR using the primers shown in Supplementary Figure S1. The relative amount of A2451U containing 25S rRNA was normalized to that of WT 25S rRNA with the 18-nt insertion. 


\section{Supplementary Figure S5}

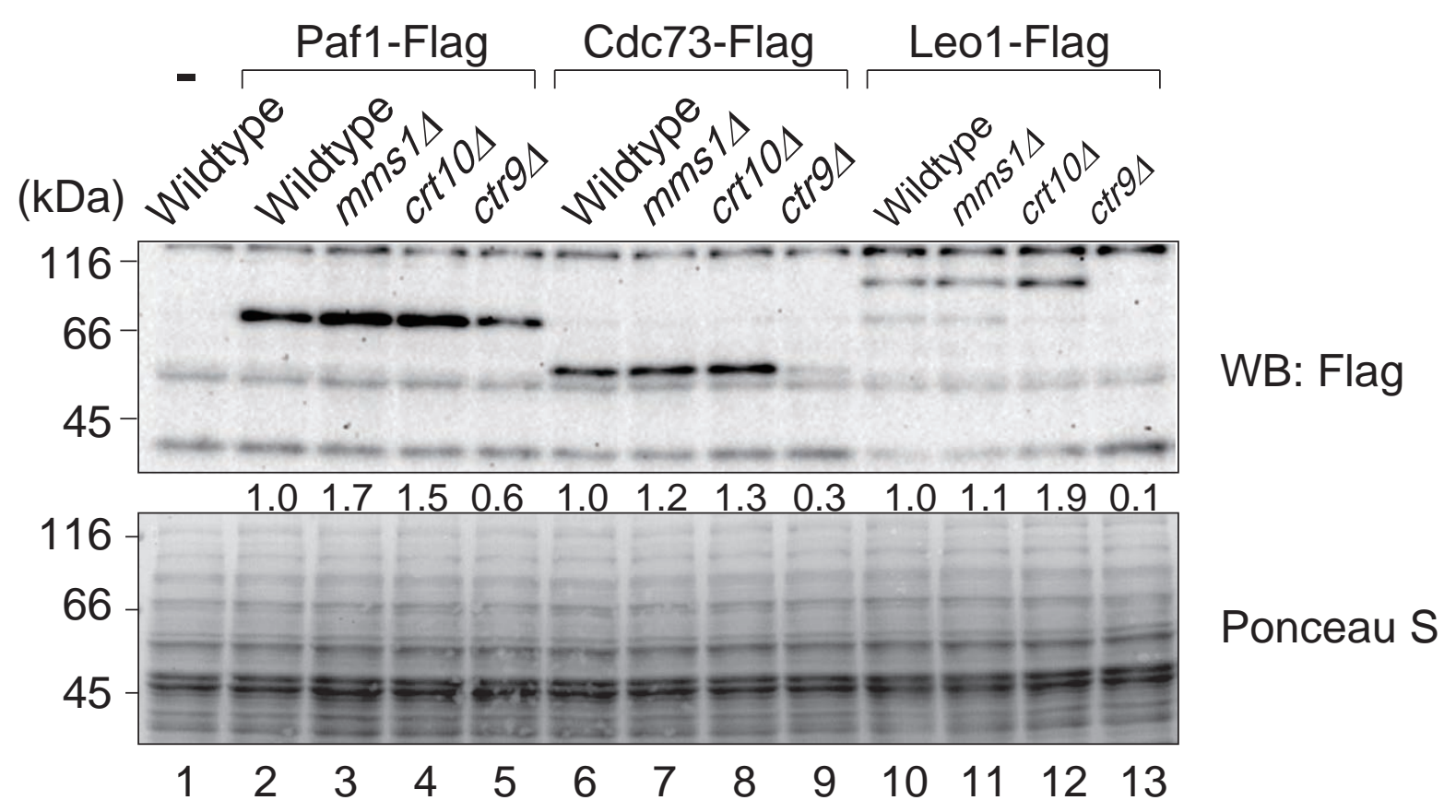

Figure S5. Crt10 partially regulated the abundance of the Paf1C complex. The yeast cell lysates expressing pPaf1-Flag, pCdc73-Flag, or pLeo1-Flag in the indicated deletion strains were analyzed by anti-Flag immunoblotting.

The same membrane was stained by Ponceau S. Numbers between the two panels indicate the intensity of Paf1-Flag, Cdc73-Flag, or Leo1-Flag normalized to that in the wild type strain. 


\section{Supplementary Figure S6}

Genes up regulated in the paf1 $\Delta$ strain

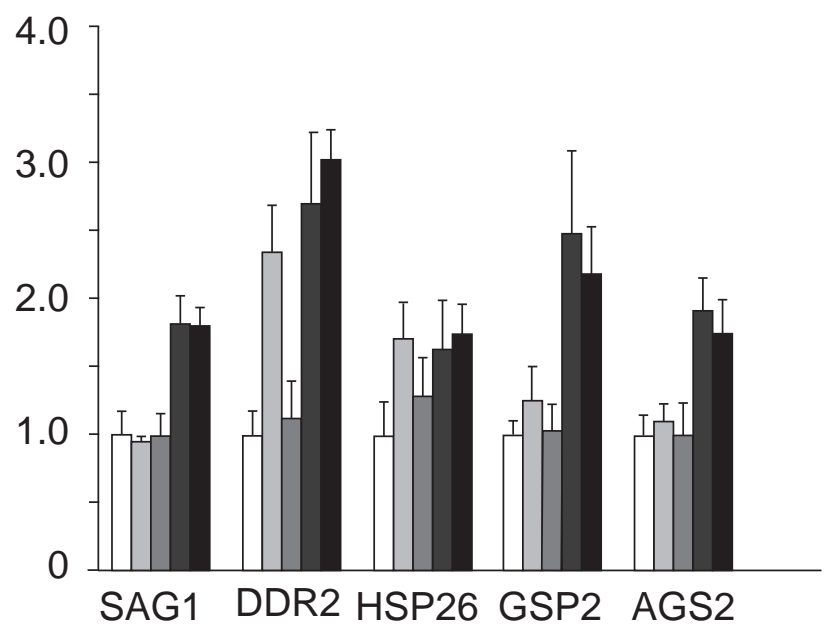

$\square$ Wild Type $\square$ mms14
Genes down regulated in the paf1 strain

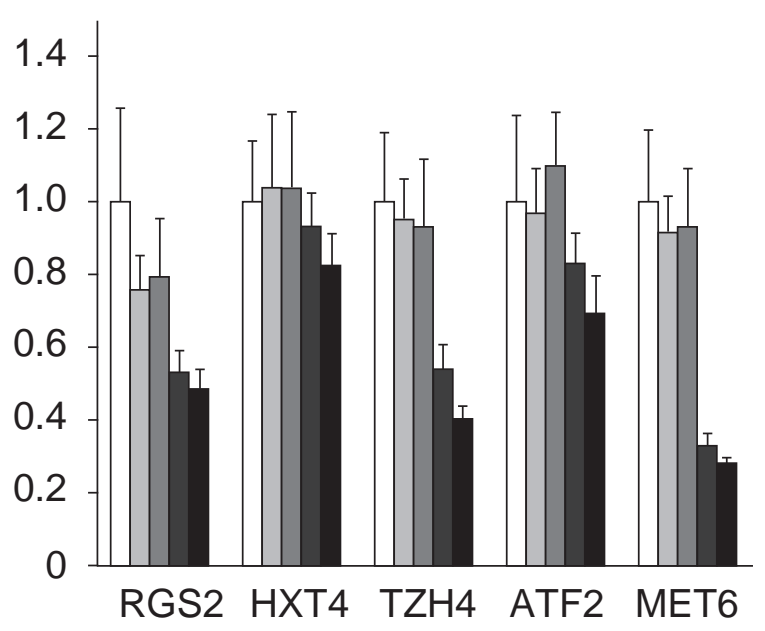

$\square \operatorname{crt104}$

- $\operatorname{ctr94}$

- paf1s

Figure S6. qRT-PCR quantification of the transcription products regulated by Paf1C.

The amount of each transcription product was normalized by qRT-PCR of endogenous rRNA. 
Supplementary Table S1: Plasmids used in this study.

\begin{tabular}{|c|c|c|}
\hline Plasmid & Notes & Reference \\
\hline pWT1 & 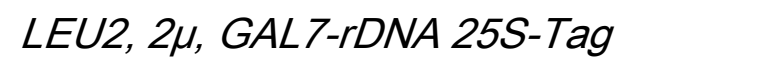 & Fujii et al, 2009 [1] \\
\hline pA2451U & LEU2, $2 \mu$, GAL7-rDNA 25S-Tag A2451U & Fujii et al, 2009 [1] \\
\hline pC2585A & $\begin{array}{l}\text { LEU2, } 2 \mu, G A L 7-r D N A 25 S-T a g \\
\text { C2452G }\end{array}$ & Fujii et al, 2009 [1] \\
\hline pU2585A & LEU2, $2 \mu$, GAL7-rDNA 25S-Tag U2585A & Fujii et al, 2009 [1] \\
\hline pRS313 & HIS3, CEN & Sikorski \& Hieter, 1989 [2] \\
\hline pCRT10-HA & HIS3, CEN, CRT10-HA & This study \\
\hline YCplac111 & LEU2, CEN, lacZ & Gietz \& Sugino,1988 [3] \\
\hline pRPL11A-Flag & LEU2, CEN, lacZ, RPL11A-Flag & This study \\
\hline pRS316 & URA3, CEN & This study \\
\hline pPAF1-Flag & URA3, CEN, PAF1-Flag & This study \\
\hline pLEO1-Flag & URA3, CEN, LEO1-Flag & This study \\
\hline pCDC73-Flag & URA3, CEN, CDC72-Flag & This study \\
\hline pYO323 & HIS3, $2 \mu$ & Qadota et al, 1992 [4] \\
\hline pMyc-Ub & HIS3, $2 \mu, C U P 1-M y c-U b i-C Y C 1$ & Fujii et al, 2009 [1] \\
\hline
\end{tabular}


Supplementary Table S2: Yeast strains used in this study.

\begin{tabular}{|c|c|c|}
\hline Strain & Genotype and Notes & Reference \\
\hline BY20693 & MATa, his3- $\Delta 1$, leu2- $\Delta 0$, ura3- $\Delta 0$ & $\begin{array}{l}\text { Brachmann et } \\
\text { al,1998 [5] }\end{array}$ \\
\hline$e s c 2 \Delta$ & $\begin{array}{l}\text { MATa, his3- } \Delta 1, \text { leu2- } \Delta 0, \text { ura3- } \Delta 0, \operatorname{met} 15 \Delta 0, \\
\text { esc2 } \Delta \because K a n M X 4\end{array}$ & $\begin{array}{l}\text { Open Biosystems } \\
\text { YKO }\end{array}$ \\
\hline ctf4 $\triangle$ & $\begin{array}{l}\text { MATa, his3- } \Delta 1 \text {, leu2- } \Delta 0, \text { ura3- } \Delta 0, \operatorname{met} 15 \Delta 0 \text {, } \\
\operatorname{ctf} 4 \Delta \because \text { KanMX4 }\end{array}$ & $\begin{array}{l}\text { Open Biosystems } \\
\text { YKO }\end{array}$ \\
\hline \multirow[t]{2}{*}{$\operatorname{tdh} 2 \Delta$} & MATa, his3- $\Delta 1$, leu2- $\Delta 0$, ura3- $\Delta 0, \operatorname{met} 15 \Delta 0$, & Open Biosystems \\
\hline & $\begin{array}{l}\operatorname{tdh} 2 \Delta:: \text { KanMX4 } \\
\text { MATa, his3- } \Delta 1, \text { leu2- } \Delta 0, \text { ura3- } \Delta 0, \operatorname{met} 15 \Delta 0,\end{array}$ & $\begin{array}{l}\text { YKO } \\
\text { Open Biosystems }\end{array}$ \\
\hline $\operatorname{srs} 2 \Delta$ & $\begin{array}{l}\text { srs } 2 \Delta:: \text { KanMX4 } \\
\text { MATa, his3- } \Delta 1 \text {, leu2- } \Delta 0, \text { ura3- } \Delta 0, \operatorname{met} 15 \Delta 0,\end{array}$ & $\begin{array}{l}\text { YKO } \\
\text { Open Biosystems }\end{array}$ \\
\hline $\operatorname{crt10} \Delta$ & $\begin{array}{l}\operatorname{ctr} 10 \Delta: \text { KanMX } 4 \\
\text { MATa, his3- } \Delta 1, \text { leu2- } \Delta 0, \text { ura3- } \Delta 0, \operatorname{met} 15 \Delta 0,\end{array}$ & $\begin{array}{l}\text { YKO } \\
\text { Open Biosystems }\end{array}$ \\
\hline por1 4 & $\begin{array}{l}\text { por1 } \Delta: \text { KanMX4 } \\
\text { MATa, his3- } \Delta 1, \text { leu2- } \Delta 0, \text { ura3- } \Delta 0, \operatorname{met} 15 \Delta 0,\end{array}$ & $\begin{array}{l}\text { YKO } \\
\text { Open Biosystems }\end{array}$ \\
\hline$m m s 1 \Delta$ & $\begin{array}{l}\text { mms1 } \Delta: \text { KanMX4 } \\
\text { MATa, his3- } \Delta 1, \text { leu2- } \Delta 0, \text { ura3- } \Delta 0, \operatorname{met} 15 \Delta 0,\end{array}$ & $\begin{array}{l}\text { YKO } \\
\text { Open Biosystems }\end{array}$ \\
\hline$r t t 101 \Delta$ & $\begin{array}{l}\text { rtt101 } \Delta:: \text { KanMX4 } \\
\text { MATa, his3- } \Delta 1, \text { leu2- } \Delta 0, \text { ura3- } \Delta 0, \operatorname{met} 15 \Delta 0,\end{array}$ & $\begin{array}{l}\text { YKO } \\
\text { Open Biosystems }\end{array}$ \\
\hline$m m s 224$ & mms22 $\triangle:$ KanMX4 & YKO \\
\hline mms $1 \Delta \operatorname{crt} 10 \Delta$ & $\begin{array}{l}\text { MATa, his3- } \Delta 1 \text {, leu2- } \Delta 0, \text { ura3- } \Delta 0, \text { met15 } \Delta 0 \text {, } \\
\text { mms1 } \Delta: \text { KanMX4, crt10 } \therefore: \text { hphMX6 }\end{array}$ & This Study \\
\hline $\begin{array}{l}\text { MMS1-Flag, } \\
\text { CRT10-HA }\end{array}$ & MATa, his3- $\Delta 1$, leu2- $\Delta 0$, ura3- $\Delta 0, \operatorname{met} 15 \Delta 0$, & This Study \\
\hline $\begin{array}{l}\text { CRT10-HA } \\
\text { MMS1-Flag, } \\
\text { rtt101 } 4\end{array}$ & 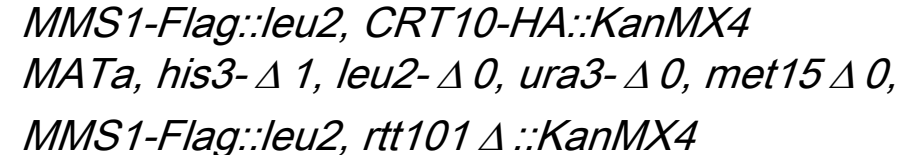 & This Study \\
\hline $\begin{array}{l}\text { MMS1-Flag, } \\
\text { crt10 } 4\end{array}$ & $\begin{array}{l}\text { MATa, his3- } \Delta 1 \text {, leu2- } \Delta 0, \text { ura3- } \Delta 0, \text { met15 } \Delta 0 \text {, } \\
\text { MMS1-Flag::leu2, crt10 } \Delta \because: \text { KanMX4 }\end{array}$ & This Study \\
\hline $\begin{array}{l}\text { RTT101-Flag, } \\
\text { mms1 } 4\end{array}$ & $\begin{array}{l}\text { MATa, his3- } \Delta 1 \text {, leu2- } \Delta 0 \text {, ura3- } \Delta 0, \text { met15 } \Delta 0 \text {, } \\
\text { RTT101-Flag::leu2, mms1 } \Delta:: K a n M X 4\end{array}$ & This Study \\
\hline $\begin{array}{l}\text { RTT101-Flag, } \\
\text { crt10 } 4\end{array}$ & $\begin{array}{l}\text { MATa, his3- } \Delta 1 \text {, leu2- } \Delta 0, \text { ura3- } \Delta 0, \text { met15 } \Delta 0 \text {, } \\
\text { RTT101-Flag::leu2, crt10 } \Delta:: K a n M X 4\end{array}$ & This Study \\
\hline CDC34 tet-off & $\begin{array}{l}\text { MATa, his3- } \triangle 1 \text {, leu2- } \triangle 0, \text { ura3- } \\
\triangle 0, U R A 3:: C M V-t T A,\end{array}$ & $\begin{array}{l}\text { Hughes et al, } \\
2000[6]\end{array}$ \\
\hline paf1 $\Delta$ & $\begin{array}{l}\text { MATa, his3- } \Delta 1 \text {, leu2- } \Delta 0, \text { ura3- } \Delta 0, \\
\text { paf1 } \Delta: \text { :KanMX4 }\end{array}$ & This Study \\
\hline $\operatorname{ctr9} \Delta$ & $\begin{array}{l}\text { MATa, his3- } \Delta 1 \text {, leu2- } \Delta 0, \text { ura3- } \Delta 0, \\
\operatorname{ctr9} \Delta:: K a n M X 4\end{array}$ & This Study \\
\hline
\end{tabular}


Supplementary Table S3: Oligos used in this study.

\begin{tabular}{|c|c|c|}
\hline Name & Sequence & Notes \\
\hline MK251 & 5'-GACCTCAAATCAGGTAGGAGTACCC-3' & 25S rRNA sequence \\
\hline MK253 & 5'-CACCGAAGGTACACTCGAGAGCTTC-3' & $\begin{array}{l}\text { complementary to pWT1 } \\
\text { rRNA tag sequence }\end{array}$ \\
\hline Kota030 & 5'-GAAATCTGGTACCTTCGGTG-3' & $\begin{array}{l}\text { untagged } 25 \mathrm{~S} \text { rRNA } \\
\text { sequence }\end{array}$ \\
\hline Kota031 & 5'-GATTCTCACCCTCTATGACG-3' & $\begin{array}{l}\text { complementary to } \\
\text { untagged } 25 \mathrm{~S} \text { rRNA } \\
\text { upstream sequence of the }\end{array}$ \\
\hline DAY0231 & CACTTTAAGTGCAGTTACTGTGTCC & $\begin{array}{l}\text { Crt10 gene } \\
\text { complementary sequence }\end{array}$ \\
\hline DAY0232 & CAATCCTGATGAGGATTCTTCACC & to downstream of the \\
\hline DAY0233 & $\begin{array}{l}\text { TCCGGGACGTCATACGGATATCCTTGTTGAGTTG } \\
\text { TTCCATGCTC } \\
\text { CCGTATGACGTCCCGGACTATGCATAGCATATTT }\end{array}$ & construction of pCrt10-HA \\
\hline DAY0234 & TGACATTTAC & onstruction of pCrt10-HA \\
\hline toki044 & 5'-AAATTGATATATTGAAGCCTTTC-3' & $\begin{array}{l}\text { upstream sequence of the } \\
\text { Rpl11a gene }\end{array}$ \\
\hline MK838 & 5'-GTGAACAAGTGCGATTCTGATAC-3' & $\begin{array}{l}\text { complementary sequence } \\
\text { to downstream of the }\end{array}$ \\
\hline toki045 & $\begin{array}{l}\text { 5'-ATCGTCGTCCTTGTAGTCGCCGCGGCCGAT } \\
\text { TTTGTCCAAAACATCAGCATCGTAC-3' } \\
\text { 5'-ATCGGCCGCGGCGACTACAAGGACGACGAT }\end{array}$ & $\begin{array}{l}\text { construction of pRpl11a- } \\
\text { Flag } \\
\text { construction of pRpl11a- }\end{array}$ \\
\hline MK553 & GACAAGTAAGCGCATCAACAAAAACTCTATG-3' & $\begin{array}{l}\text { Flag } \\
\text { upstream sequence of the }\end{array}$ \\
\hline DAY0308 & 5'-GCCTGAATTGCATGAGGATGATGG-3' & $\begin{array}{l}\text { Paf1 gene } \\
\text { complementary sequence }\end{array}$ \\
\hline DAY0309 & 5'-CGAIAAAGAIAGI I IAACGGAGC-3' & to downstream of the Paf1 \\
\hline DAY0310 & $\begin{array}{l}\text { GTAAAGTTTCCTT-3' } \\
\text { 5'-CGACTACAAGGACGACGATGACAAGTAGAA }\end{array}$ & construction of pPaf1-Flag \\
\hline DAY0311 & TATTGAGAAGTGAA-3' & construction of pPaf1-Flag \\
\hline DAY0233 & 5'-GATAAAGACGCTGAGAAACAACG-3' & $\begin{array}{l}\text { upstream sequence of the } \\
\text { Leo1 gene }\end{array}$ \\
\hline DAY0234 & 5'-TCGAGTAGATGACAGCTTTGTCG-3' & \\
\hline DAY0235 & $\begin{array}{l}\text { 5'-TCATCGTCGTCCTTGTAGTCGCCATCCTCGT } \\
\text { CTTCGTCGTCCTC-3' } \\
\text { 5'-CGACTACAAGGACGACGATGACAAGTAGAG }\end{array}$ & construction of pLeo1-Flag \\
\hline DAY0236 & GAGACGTTACTTTG-3' & \\
\hline
\end{tabular}




\begin{tabular}{|c|c|c|}
\hline Name & Sequence & Notes \\
\hline DAY0320 & CAAAACTGCAATTGCAATGAAACC & $\begin{array}{l}\text { upstream sequence of the } \\
\text { cdc73 gene }\end{array}$ \\
\hline DAY0321 & ACAGGCCTGATATCTCCCATGG & $\begin{array}{l}\text { complementary sequence to } \\
\text { downstream of the Cdc73 }\end{array}$ \\
\hline DAY0322 & $\begin{array}{l}\text { TCATCGTCGTCCTTGTAGTCGCCACGGTATCCTCTTG } \\
\text { AAATAAG }\end{array}$ & construction of pCdc73-Flag \\
\hline DAY0323 & $\begin{array}{l}\text { CGACTACAAGGACGACGATGACAAGTGAATACGATAA } \\
\text { ACGGAAG }\end{array}$ & construction of pCdc73-Flag \\
\hline DAY541 & TCCAGTCCCTCATCTTATACGTCTT & Sag1 qRT-PCR forward \\
\hline DAY542 & GCGTAAAACTGGTGCTTAGTAATGTT & Sag1 qRT-PCR reverse \\
\hline DAY535 & CGCATCCAACACCACGAGTA & Ddr2 qRT-PCR forward \\
\hline DAY536 & CGGCGTTTAGTAGTTGACCATTT & Ddr2 qRT-PCR reverse \\
\hline DAY537 & GGGTGAAGGCGGCTTAAGAG & Hsp26 qRT-PCR forward \\
\hline DAY538 & CCTTGCCAGTAGAATCCTTTGC & Hsp26 qRT-PCR reverse \\
\hline DAY545 & GCCGGTAACCCACAATTGG & Gsp2 qRT-PCR forward \\
\hline DAY546 & GGTGCATTAGTTGCTCGTCAAC & Gsp2 qRT-PCR reverse \\
\hline DAY549 & CAATGCAGCGATCGCACTT & Rsg2 qRT-PCR forward \\
\hline DAY550 & AGGTCGAGCTGGTAGTGTTGAGT & Rsg2 qRT-PCR reverse \\
\hline DAY551 & TCGACGAGAATCACGAAGAATC & Hxt4 qRT-PCR forward \\
\hline DAY552 & ACCATTAAACAACAGATGGAAACTGT & Hxt4 qRT-PCR reverse \\
\hline DAY553 & CGATGCTGTCATTTTGTCTCCTA & Izh4 qRT-PCR forward \\
\hline DAY554 & CACCATACAAAATACAAAAACGTTCA & Izh4 qRT-PCR reverse \\
\hline DAY555 & CCGTACTACGTTCGGGATTTAATC & Atf2 qRT-PCR forward \\
\hline DAY556 & CATTCACGTTTGTGGAGCAAA & Atf2 qRT-PCR reverse \\
\hline DAY563 & TGTGATCACCAAGAACGTTTCC & Met6 qRT-PCR forward \\
\hline DAY564 & TGGATTTACCTCTGGATTCAACAG & Met6 qRT-PCR reverse \\
\hline
\end{tabular}




\section{Supplementary Materials and Methods}

\section{Plasmids}

pWT1, pA2451U, pC2452G, pU2585A, and pMyc-Ub have been described previously [1]. To construct pCrt10-HA, pRpl11a-Flag, pPaf1-Flag, pLeo1-Flag, and pCdc73-Flag, HA or a Flag tag was added to the C-terminus of each gene by overlap extension (See the Supplemental Table for all primers and plasmids used in this study). The PCR fragments of each gene, containing the promoter, ORF, tag sequence, and terminator, were cloned into pRS316 [2] or YCplac111 [3].

\section{Polysome analysis}

Yeast strains expressing the tagged rRNAs were grown in $250 \mathrm{~mL}$ of SD-Galactose to the mid-log phase. A total of $100 \mu \mathrm{g} / \mathrm{ml}$ cycloheximide (Nacalai Tesque) was added to the culture, and cells were harvested by centrifugation. The cell pellet was frozen in liquid nitrogen and then ground in liquid nitrogen using a mortar and pestle [7]. The resulting cell powder was then resuspended on ice in $0.5 \mathrm{~mL}$ of IPP150 buffer (10 mM Tris- $\mathrm{HCl}$ ( $\left.\mathrm{pH} 8.0), 150 \mathrm{mM} \mathrm{NaCl}, 2.5 \mathrm{mM} \mathrm{MgCl}_{2}, 0.1 \% \mathrm{NP} 40\right)$ supplemented with a protease inhibitor cocktail (complete mini-EDTA free; Roche) and $100 \mu \mathrm{g} / \mathrm{ml}$ cycloheximide. Extracts were then transferred to 1.5-mL Eppendorf tubes and clarified by centrifugation at $4^{\circ} \mathrm{C}$ for $5 \mathrm{~min}$ at $5,000 \times \mathrm{g}$. The supernatant was recovered and centrifuged at $4^{\circ} \mathrm{C}$ for $20 \mathrm{~min}$ at $18,000 \times \mathrm{g}$. The lysates were resolved with $10 \%-40 \%$ sucrose gradient centrifugation at $4^{\circ} \mathrm{C}$ for $150 \mathrm{~min}$ at $40,000 \mathrm{rpm}$ (Swi40Ti rotor, Beckman). Gradient Station model 153 (BioComp Instruments, Inc.) was used to collect the fractions. Dot blotting of the fractions was performed by spotting $5 \mu \mathrm{L}$ of the solution from 200- $\mu \mathrm{L}$ fractions onto a membrane (Amersham Hybond- $\mathrm{N}^{+}$, GE Healthcare). After UV cross-linking for 3 min, the membrane was probed by MK253. 


\section{Supplementary References}

[1] K. Fujii, M. Kitabatake, T. Sakata, A. Miyata, M. Ohno, A role for ubiquitin in the clearance of nonfunctional rRNAs, Genes \& Development 23 (2009) 963-974.

[2] R.S. Sikorski, P. Hieter, A SYSTEM OF SHUTTLE VECTORS AND YEAST HOST STRAINS DESIGNED FOR EFFICIENT MANIPULATION OF DNA IN SACCHAROMYCES-CEREVISIAE, Genetics 122 (1989) 19-27.

[3] R.D. Gietz, A. Sugino, NEW YEAST-ESCHERICHIA-COLI SHUTTLE VECTORS CONSTRUCTED WITH INVITRO MUTAGENIZED YEAST GENES LACKING 6BASE PAIR RESTRICTION SITES, Gene 74 (1988) 527-534.

[4] H. Qadota, I. Ishii, A. Fujiyama, Y. Ohya, Y. Anraku, RHO GENE-PRODUCTS, PUTATIVE SMALL GTP-BINDING PROTEINS, ARE IMPORTANT FOR ACTIVATION OF THE CAL1/CDC43 GENE-PRODUCT, A PROTEIN GERANYLGERANYLTRANSFERASE IN SACCHAROMYCES-CEREVISIAE, Yeast 8 (1992) 735-741.

[5] C.B. Brachmann, A. Davies, G.J. Cost, E. Caputo, J.C. Li, P. Hieter, J.D. Boeke, Designer deletion strains derived from Saccharomyces cerevisiae S288C: a useful set of strains and plasmids for PCR-mediated gene disruption and other applications, Yeast 14 (1998) 115-132.

[6] T.R. Hughes, M.J. Marton, A.R. Jones, C.J. Roberts, R. Stoughton, C.D. Armour, H.A. Bennett, E. Coffey, H.Y. Dai, Y.D.D. He, M.J. Kidd, A.M. King, M.R. Meyer, D. Slade, P.Y. Lum, S.B. Stepaniants, D.D. Shoemaker, D. Gachotte, K. Chakraburtty, J. Simon, M. Bard, S.H. Friend, Functional discovery via a compendium of expression profiles, Cell 102 (2000) 109-126.

[7] T. Inada, E. Winstall, S.Z. Tarun, J.R. Yates, D. Schieltz, A.B. Sachs, One-step affinity purification of the yeast ribosome and its associated proteins and mRNAs, Rnaa Publication of the Rna Society 8 (2002) 948-958. 